УДК 626/627

\title{
ОХРАНА ОКРУЖАЮЩЕЙ СРЕДЫ ПРИ РАБОТЕ ЖИРЕКЕНСКОГО ФЕРРОМОЛИБДЕНОВОГО ЗАВОДА
}

Мелехин Никита Павлович студент Научный руководитель: Зайцев Антон Иванович старший преподаватель ИМВХС им. А.Н. Костякова ФГБОУ ВО «Российский государственный аграрный университет МСХА им. К.А. Тимирязева»

Аннотация: Жирекенский ГОК - компания по добыче, переработке и обогащению руды с получением ферромолибдена и концентрата меди. Тип хвостохранилища - намывное для складирования подаваемых гидравлическим транспортом отвальных хвостов и создания емкости, обеспечивающей осветление оборотной воды. В технологическом процессе производства ферросплавов образуются загрязняющие вещества, которые оказывают негативное влияние на окружающую среду. Возможно, что завод в будущем перестанет работать и встанет вопрос по поводу рекультивации хвостохранилищ.

Ключевые слова: ферромолибден, намыв хвостов, хвостохранилище, оборотная вода, окружающая среда, защита атмосферы, рекультивация.

\section{ENVIRONMENTAL PROTECTION DURING THE OPERATION OF ZHIREKENSKY FERROMOLYBDENUM PLANT}

\author{
Melekhin Nikita Pavlovich \\ Academic Supervisor: Zaitsev Anton Ivanovich \\ Institute of Melioration, Water Management and Construction \\ Russian State Agrarian University - \\ Moscow Timiryazev Agricultural Academy
}

Abstract: Zhirekensky GOK is a company for the extraction, processing and concentration of ore with the production of ferromolybdenum and copper 
concentrate. Tailings dump type - upstream for storage of dump tailings supplied by hydraulic transport and creation of a tank that provides clarification of circulating water. In the technological process of ferroalloys production, pollutants are formed that have a negative impact on the environment. It is possible that the plant will stop working in the future and the question will arise about the reclamation of tailings.

Key words: ferromolybdenum, tailings leaching, tailing dump, recycled water, environment, atmosphere protection, reclamation.

\section{Введение}

Жирекенский ГОК - российская компания по добыче, переработке и обогащению руды Жирекенского месторождения с получением ферромолибдена и концентрата меди. Компания разрабатывает Жирекенское месторождение молибденово-медных руд в Читинской области. Является градо- и бюджетообразующим предприятием муниципального образования «Жирекенское» и одним из крупнейших горнорудных предприятий Забайкальского края.

Хвостохранилище обогатительной фабрики ООО «Жирекенский ФМЗ» запроектировано на складирование отвальных хвостов до конечной отметки заполнения - 751,00 м и расположено в долине ручья Топаки. Тип хвостохранилища - намывное и служит для складирования подаваемых гидравлическим транспортом отвальных хвостов и создания емкости, обеспечивающей осветление оборотной воды. Основной водной артерией района является река Алеур.

Процесс получения ферромолибденового сплава происходит при температуре $1800^{\circ} \mathrm{C}$. Во время плавки в атмосферу выбрасываются оксид углерода, диоксид азота, фтористый водород и твердые взвешенные частицы шихты, которые осаждаются на почве и растениях. Под воздействием климатических условий происходит выщелачивание материалов шихты и усвоение содержащихся в ней элементов через корневую систему, а оседание пыли на поверхности наземной части растений приводит к снижению интенсивности процесса фотосинтеза. В технологическом процессе производства ферросплавов образуются загрязняющие вещества, которые оказывают негативное влияние на окружающую среду, в частности, на атмосферу. Доставленное на завод сырьё загружается и хранится на складах, где происходит выделение кремнийсодержащей пыли, также пыль выделяется при дроблении, сортировке и загрузке шихтовых материалов. Места 
выделения пыли оснащены отсосами для улавливания и очистки пылевоздушной смеси в пылеулавливающих установках.

На основании данных натурных наблюдений и обследований хвостохранилища основная проблема, которая была выявлена - это намораживание части хвостов при складировании в зимний период и связанный с этим дефицит воды. Поэтому складирование хвостов в верховьях хвостохранилища является наиболее эффективным. Естественно, при соблюдении безопасных параметров «низовой» ограждающей дамбы. Для реализации «стратегического» превышения отметок заполнения в верховьях хвостохранилища требуется прокладка верхней трассы гидротранспорта, что позволит гарантировано вести складирование хвостов от верховой плотины в течение всего срока эксплуатации (рис. 1.).

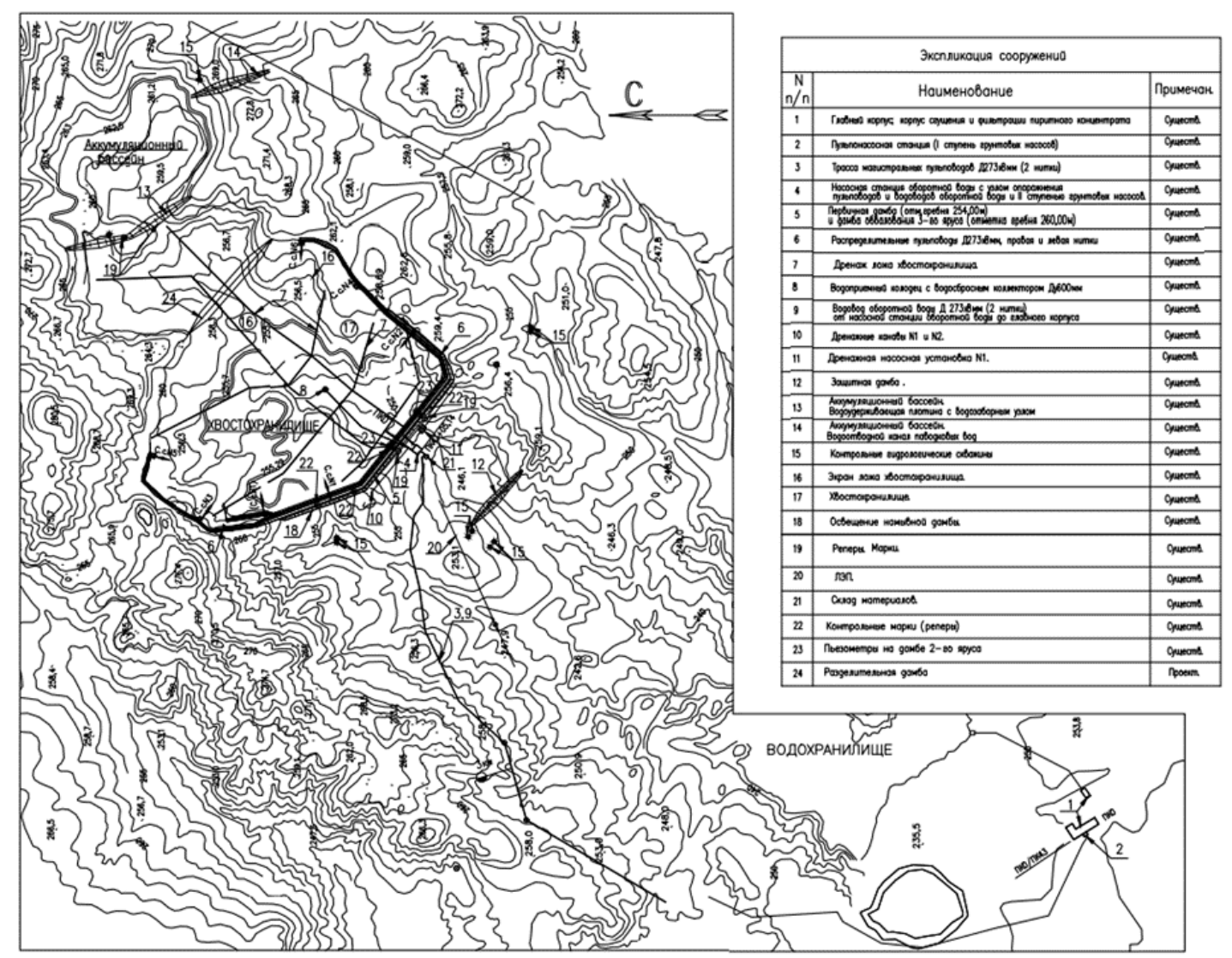

Рис. 1. Схема сооружений

При устройстве хвостохранилища загрязнение воздушного бассейна в основном происходит при пылении хвостовых отложений, находящихся в воздушно-сухом состоянии, при высоких скоростях ветра. Лабораторными исследованиями и полевыми замерами установлено, что хвосты аналогичного 


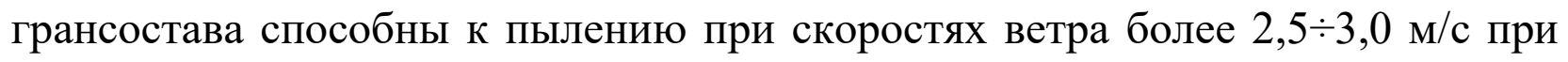
влажности менее 2\%. В климатических условиях Жирекенского месторождения максимальное количество осадков выпадает в июне-августе, т.е. пляжи хвостохранилища в летний период будут увлажняться и атмосферными осадками. При проектировании хранилищ должны предусматриваться мероприятия, максимально уменьшающие последствия ветровой эрозии, в результате которой загрязняются атмосферный воздух, почвы, водоемы как в период строительства и эксплуатации сооружений, так и в период консервации. Создание защитного покрытия откоса требует учета особенностей конкретного сооружения (климат района, химикоминералогический состав намытых отходов); обработки поверхностного слоя откоса различными химическими соединениями (эмульсии на основе битумов, синтетических полимеров, силикат растворов, укрытие пленками) [1].

В зимний период складирование предусматривается вести через сосредоточенные сбросы, как с низовой ограждающей дамбы, так и на правом борту хвостохранилища в направлении отстойного пруда. Начинать складирование хвостов по зимней схеме целесообразно в ноябре, при установившейся среднесуточной температуре атмосферного воздуха ниже минус $5^{\circ} \mathrm{C}[2]$. Контроль и наблюдения за работой сооружений хвостового хозяйства необходимо проводить в соответствии с требованиями «Правил безопасности» в объеме, предусмотренном местной инструкцией по эксплуатации. В инструкции должны быть отражены вопросы безопасной эксплуатации оборудования и сооружений всех систем хвостового хозяйства, а также вопросы производственной санитарии, противопожарной защиты при работе всех систем [3].

Основным фактором отрицательного воздействия хвостохранилища является влияние фильтрационных вод на естественные грунтовые воды, которые уменьшаются дренажными сооружениями, расположенными за низовым откосом дамбы. При работе дренажной насосной установки исключается попадание фильтрующих из хвостохранилища вод в естественные водотоки, а также подтопление и заболачивание территории, прилегающей к хвостохранилищу [4]. Дренажные воды, аккумулируемые в водоеме у защитной дамбы хвостохранилища, перекачиваются в хвостохранилище на пополнение отстойного пруда.

Одним из основных контрольных параметров для обеспечения безопасной эксплуатации хвостохранилища с точки зрения влияния на 
гидросферу, является положение кривой депрессии в пьезометрических створах, определяемое по показаниям пьезометров и необходимо следить, чтобы фактические параметры эксплуатируемого хвостохранилища соответствали «Критериями безопасности гидротехнических сооружений» $[3,5]$. Это превышение отметки надводного пляжа у верхового откоса дамбы обвалования над уровнем воды отстойного пруда - не менее 1,0 м; - длина пляжа - не менее 30 м; -генеральный уклон низового откоса - не круче 1:4.

Контроль химического состава фильтрационных вод должен проводиться службой натурных наблюдений (службой мониторинга). Работа обогатительной фабрики предусматривается при полном водообороте технологических вод: сброса в поверхностные водоемы не производится.

Для предотвращения загрязнения атмосферного воздуха в теплый период года предусмотрена отсыпка дамб обвалования из скального грунта, что исключает пыление низового откоса, а технология проведения намывных работ и подъем горизонта воды прудка хвостохранилища предусматривают поддержание пляжной зоны в увлажненном состоянии, что исключает пыление с пляжа.

Выводы: данный завод функционирует, но его прибыль за последние несколько лет, а точнее с 2015 года отрицательна. Исходя из этого можно предположить, что, возможно, завод в будущем перестанет работать, и тогда встанет вопрос по поводу уборки его хвостохранилищ [6]. В ходе обработки и получения ферромолибдена выделяется огромное количество шлака и различных вредных веществ, использовать которые вторично затруднительно и стоит учесть, что пыль молибдена и его соединений раздражает дыхательные пути, при длительном вдыхании - неизлечимое и необратимое заболевание (пневмокониоз). Также могут развиться полиартралгии, артрозы, гипотония, в крови может снизиться концентрация гемоглобина, число эритроцитов и лейкоцитов. Существуют способы добычи из данной пыли некоторых химических элементов и уменьшению её выделения.

\section{Список литературы}

1. Зимнюков, В.А., Зборовская, М.И., Абрамова, М.А. Влияние природных факторов на работу шламонакопителя. В сборнике: ДОКЛАДЫ ТСХА. Материалы международной научной конференции. 2018. С. 177-179.

2. Зимнюков, В.А., Зборовская, М.И. Разработка технологии укладки отвальных хвостов в зимнее время при эксплуатации гидротехнических 
сооружений хвостохранилища. В сборнике: Современные проблемы развития мелиорации и пути их решения (Костяковские чтения). Материалы международной научно-практической конференции. Москва, 2020. С. 299-304.

3. Правила безопасности гидротехнических сооружений накопителей жидких промышленных отходов. ПБ-03-438-02, СПб, ЦОТПБСП, 2002г.

4. Зборовская, М.И., Зимнюков, В.А., Козимиров, Н.Ю. Значение водных объектов в формировании экологического каркаса урбанизированной территории. В сборнике: Экологические и биологические системы. Сер. "Ecological studies, hazards, solutions" Отв. редакторы: С.В. Котелевцев, С.Н. Орлов, О.М. Горшкова, С.А. Остроумов. Москва, 2015. С. 20-23.

5. Федеральный закон от 21 июля 1997 года N 117-Ф3 "О безопасности гидротехнических сооружений" (с изменениями на 8 декабря 2020 года).

6. Зимнюков, В.А., Зборовская. М.И., Белавкин, А.В. Учет экологических факторов при оценке жизненного цикла гидротехнических сооружений. В сборнике: Экологические и биологические системы. Cep. "Ecological studies, hazards, solutions". Отв. редакторы: С.В. Котелевцев, С.Н. Орлов, О.М. Горшкова, С.А. Остроумов. Москва, 2015. С. 23-27.

(C) Н.П. Мелехин, 2021 